\title{
The Adoption and Use of Social Media and Its Impact on Mainstream Media in Bahrain
}

\author{
Hatem Alsridi \\ University of Bahrain, Zallaq, Kingdom of Bahrain
}

\begin{abstract}
The adoption and use of social media has played a major role in the changes in journalists' work. The use of these new means has become indispensable to the daily tasks and work of journalists in most news organizations. It is no longer possible to bypass these means when it comes to searching for information and news, or in production, publishing, distribution and marketing, or even in interaction with the public. The characteristics of ease, speed, immediacy, interactivity, and being free of charge that characterize them, have made them a useful technological tool, which is influential and necessary not only for the future of the journalist's career but also for the future of the news organization itself. With the growing number of users of social media around the world, journalists and news organizations have found additional access, more important than previous channels, to access additional sources that help them market and interact with their work in a new dynamic environment completely different from previous communication models, and put audience activity at the forefront. In this study, which is part of the Technology Acceptance Model (TAM), the author tries to understand and analyze the factors of adoption and use of social media as a new technological tool by Bahraini journalists and to identify their new role in the changes in journalism. In addition, the study attempts to examine the implications in relation to the future of the press profession and the economic model of the news organization. The results showed a clear adoption and an increased use of social media by journalists, who consider it a key element in the development of journalism, and an inevitable strategic choice for the future of the news organization. They also expressed their full awareness of the problems surrounding the issue of precision and credibility of news accessed through social media.
\end{abstract}

Keywords: social media, Technology Acceptance Model (TAM), mainstream media, Bahrain

\section{Introduction}

The Arab region is one of the areas that most widely use social media in the world (Dennis, Martin, \& Wood, 2017). The WhatsApp application tops the list of social media use (67\%), followed by Facebook by (65\%) and YouTube by (50\%).

According to January 2018 statistics, the number of Internet users in the Kingdom of Bahrain is estimated at 1.5 million (Kemp, 2018), accounting for $98 \%$ of the total population. The number of mobile subscriptions is estimated at 3.5 million, or $229 \%$ of the total population. The number of social media users is estimated at 1.4 million (Kemp, 2018), or $92 \%$ of the population. Facebook comes in first with 1.4 million users, followed by Instagram with 660,000 users.

These statistics are important because the rate of subscriptions and the high use of social media influence

Hatem Alsridi, Assistant Professor, Department of Mass Communication, University of Bahrain. 
the public's relationship with news sources. This will also help us analyze and understand the adoption and impact of the use of these networks on the work of the mainstream media in the Kingdom of Bahrain and to develop the profession of the journalist in more comprehensively in terms of searching for information, production, and dissemination of news, marketing, and interaction with users.

The use of modern technology in journalism, including the Internet and social networks, has been the focus of many researches and studies that have sought to analyze and study the impact of employing and adopting modern technology on the press and career development environment in relation to information search, as well as the new ways of interacting with the public and gaining confidence and broadening the grass roots of the news organization.

Pavlic (2000) believed that journalism has always been shaped by technology and emphasized that its effect is produced through four basic elements: (1) how journalists do their work; (2) the news content; (3) the structure of the news industry; and (4) the relationship between the news organizations and their publics.

The results of the European study on the impact of the Internet on the press (Fortunati et al., 2009) indicate that European journalists positively evaluate the role of the Internet in the physical and practical organization of the news group. They welcome it when it suits developing skills, practice, and professional goals. They believe it facilitates and speeds up journalism, improves the impact of their work on the public, and enables clearer relationships with readers.

In a study on the impact of the Internet on print journalism in Portugal (Bastos, Lima, \& Moutinho, 2010), journalists see the Internet as a useful tool that meets practical professional needs, such as speed, dissemination, information gathering, and interaction. The same results of a similar study on the impact of the Internet on radio journalism in Portugal (Bastos, Lima, Moutinho, \& Reis, 2012) confirm the positive role of the Internet for journalists who find it useful to search for breaking news; to ascertain the context of the news. In addition to its important impact on press functions, including the rapid gathering of news and continuous communication with the public as well as broadcast news of credibility and new ideas.

Some researchers underestimate the negative view of the impact of technology on the journalists' profession, since the so-called networked journalism (Van Der Haak, Parks, \& Castells, 2012) in the digital age does not threaten the independence and quality of journalistic work, as it helps journalists to free themselves from strict corporate control. It is therefore an opportunity for journalists to develop creativity and share it across the network.

Journalists in Nigeria are well aware of the importance of the Internet in journalism (Uwom, Ajaegbu, Oloyede, \& Sowemimo-Coker, 2014). They believe it is important in accessing information and publishing news; it has helped to improve the speed of news production in the institution, and has created a new way of dialogue with the public. In a similar study, journalists in southeastern Nigeria see social media as helping to collect and disseminate news, but have negative effects on journalists (Didiugwu, Ezugwu, \& Ekwe, 2015). In Galingo, Nigeria, journalists are increasingly accepting the use of the Internet and social networks in journalism, especially Facebook for its widespread use in the country (Apuke, 2016). They also believe that these networks enhance the effectiveness of their work by increasing media sources and disseminating news.

The use of the Internet has increased in the work of the press and the social media has entered the newsrooms, and become the most important new technological tools used by journalists, whether for information gathering or news production and dissemination or communication and interaction with the public. The social media accounts of news organizations have sometimes become more important than the websites of 
these same institutions (Alsridi, 2018). The profession of journalism was once again influenced by technology (Pavlic, 2000). News organizations have had to develop journalistic practice and enhance their presence by means of social media, revisiting the economic model of the news organization in the midst of all these developments.

The results of the Global Social Journalism Study in the United States (Cision, 2017) show that social media are the most widely used platforms by journalists using at least five types of platforms. According to the same study, publishing, distributing, and marketing of content are the main drivers of the use of social media and its activities. Interaction with the public is one of the most important activities of journalists on social networks, with $19 \%$ interacting with the public every hour, and $47 \%$ once a day. Less than half (48\%) believe they cannot complete their journalistic work without using social media. Another study suggests that two-thirds of Americans receive news via social media, but most expect it to be inaccurate (Matsa \& Shearer, 2018).

Lee (2015) saw social media as a double-edged sword, as they reflect opportunities and problems. On the personal level, interaction with the public contributes to an increase in the personal character of the journalist. On the professional level, this interaction contributes to the reduction of the professional value of the journalist.

The 2017 Digital Report of the Reuters Institute of the University of Oxford (Newman, Fletcher, Kalogeropoulos, Levy, \& Nielsen, 2017) showed an increase in the spread of news via social media, especially through messaging applications, which became more popular, thanks to its privacy feature. WhatsApp use for the news has competed fiercely with Facebook in many countries, such as Malaysia (51\%), Brazil (46\%), and Spain (32\%).

A study of social media and journalistic practice (Bossio, 2017) shows that social media cultures that prioritize openness and collaboration with the public are adopted by journalists and challenge the way in which traditional practices are assessed in this area. Nevertheless, it is impossible to understand the press and social media without understanding the processes of collaboration, sharing and exchange that distinguish the relationship between the press and the public.

In a study on the awareness of journalists and users of fact-finding via social media (Brandtzaeg, Følstad, \& Domínguez, 2017), the researchers identified three key factors that would facilitate the most meaningful and reliable use of social media: (1) recognition of limited verification; (2) Transparency; and (3) verifying facts through collaboration with users.

A study on the impact of social media on journalism in South India (Neelima, 2015) shows that journalists face a major challenge of adapting to the changing patterns of news consumption among the public and learning to use social media to keep up with the evolving forms of journalism.

Social media are not a heresy (Bullard, 2013), but are clearly used by the public for accessing news and information. News organizations also recognize that social media platforms provide a new tool for news dissemination and business marketing.

In a study on the use of social media in Nepal (Acharya, Pathak, Karki, Bhandari, \& Dahal, 2012), it is indicated that journalists clearly use these tools extensively and believe that social media and the Internet are becoming the most important tool used in the formulation and marketing of news. However, they do not believe in the reliability of news via social media.

With the advent of social media, news gathering is no longer confined only to journalists, but has become a different form that is a part of an environmental system for the exchange of information by sources, readers, and opinions (Acharya et al., 2012). 
Newman (2009) argued that social media and user-generated content are increasingly moving in the forefront and affect the strategic direction and practice of journalism. There is a growing consensus that citizen journalism and social media will not take the place of traditional journalism, but will complement it.

Changes in the use of modern technology and social media in journalism have affected news organizations and the journalistic profession. This led to journalists and journalism being negatively affected (Chang-de, 2015). Journalism has changed from a "reliable and serious news provider" to a passionate and biased publisher of light news.

Anderson (2011) observed that online news monitoring and measuring techniques, such as measuring the number of pages visited or measuring the popularity of news stories seem to re-make decision-making in the journalistic field, redefining the role of the public from an ineffective element that consumes the news determined by journalists to an actor who gives quantitative feedback about his options.

At the Arab level, the media operate in a traditional format. With the exception of the digital news update feature, there are only minor differences between the digital version and the printed version of newspapers, and the potential of the Internet is not exploited (Ben Moussa \& Douai, 2014).

In a study on the adoption and use of social media as a source of news by Egyptian media journalists (Mansour, 2016), journalists agree that these means are available and updated sources of news. They also consider them to be accurate, appropriate, reliable, and easy-to-access sources of information and promote journalistic work. Yet, journalists have reported some of the challenges they face in using social media as a source of news, including lack of knowledge of how to refer to the source, and lack of time to access them.

Social media are constantly influencing the press, as interaction with potential readers and sources of news has moved away from the traditional role of journalists in Jordan (Amjad, 2018). The functions and responsibilities of the Jordanian journalist have changed to focusing on enhancing relationships on the web, tracking news stories faster, and maintaining interaction with readers in a climate that is consistent with the speed and dynamism of social media work.

In the Kingdom of Bahrain, news organizations have enormous technological potential in terms of the use of the Internet and social networks in the process of production, publishing, and interaction with the public (Alsridi, 2018), but this use does not reflect a clear vision or strategy that defines the Business model of the news organization and the role of modern technology in supporting journalistic work and diversifying the organization's income sources using new opportunities offered by technology (Dagiral \& Parasie, 2010).

Much of the content of the Bahraini newspapers remains on the Web, simply copying and pasting the content of the paper version of these newspapers, not realizing that the strategy of producing and managing paper content is radically different from the digital content (Alsridi, 2011). Thus, those in charge in the Bahraini news organizations miss the opportunity to make the best use of the new possibilities provided by modern technology within the concepts of developing the business climate and diversifying the sources of the news organization's income.

Research and studies on the use of the news organizations in the Kingdom of Bahrain for modern technology in promoting journalistic work remain scarce and do not analyze in depth the use of technology and its relation to changing the climate of journalism and the wider development of journalism.

\section{Theoretical Background}

To examine the factors of adoption and use of social media and its impact on journalism in the Kingdom 
of Bahrain, the author has used the Technology Acceptance Model (TAM), which was founded by Fred D. Davis in 1989. This model has contributed to the development of concepts of benefit from the use of technology and ease of use (Mansour, 2016). It also considers that the recognition of the benefit from the use and ease of use of technology heavily affects the adoption of use and ultimately on performance at work.

Davis proposed in 1985 that the use of the system is a response that can be interpreted or predicted by stimulation of the user, who in turn is directly affected by an external stimulus consisting of the features and capabilities of the actual system (Chuttur, 2009).

This theory is one of the most famous theories that have been used in scientific studies for about 30 years. It seeks mainly to understand the factors and reasons for accepting or rejecting the use of technology and its potential effects on performance.

This study considers that the theory of acceptance of technology is the closest theoretical framework that helps us to study and understand the factors that Bahraini journalists adopt for using social media as a new technology and tool, and to answer the question of whether this technology helps them enhance journalism through the advantages and features that they offer in the ease of searching; on information and speed in the dissemination of news and mass distribution, and the marketing of content and interaction with the public. It also helps to understand the impact of this use on changing the journalistic environment, the professional performance of journalists, and on the future of mainstream media.

\section{Research Questions}

RQ 1: Do Bahraini journalists consider the adoption and use of social media as a catalyst to enhance the production of journalism and the fastest way to access and disseminate news, and an opportunity for more communication and interaction with the public?

$\mathrm{H}$ 1: The younger journalists are the most responsive to the use of social media to promote the process of news production.

H 2: Journalists who receive training on the use of social media are the most responsive to social media to enhance the production process of journalism.

RQ 2: Do journalists consider the changes made by social media as positive or negative changes to the journalist's career and the future of the news organization?

$\mathrm{H}$ 1: It is difficult for journalists to identify this change.

$\mathrm{H}$ 2: Older journalists are more aware of these changes.

H 3: Journalists who work full-time are more aware of these changes.

\section{Methodology}

A questionnaire has been prepared for the study and was arbitrated by two members of the Scientific Research Committee at the Mass Communication Department, University of Bahrain. It was randomly distributed to 10 Bahraini journalists working for different news organizations. As a result, some questions were removed and others were modified to avoid problems observed in the content of the questionnaire.

Subsequently, the questionnaire was distributed to a random sample of Bahraini journalists, most of whom belong to the Bahraini Journalists Association and worked in the print, audio-visual and electronic media, and also the official Bahrain News Agency. It was distributed in electronic form through Survey Monkey software $(N=211)$, and directly through the printed form $(N=80)$, in order to give an opportunity for all participants in 
the study to use the method of their preference in filling the form. As a result, 291 questionnaire forms were collected, representing 50\% of the number of journalists registered under the Bahraini Journalists Association, according to official statistics issued by the Bahrain Journalists Association (2018). The collection process was completed between 1 April and 31 May 2018.

Thirty-six forms did not meet the scientific criteria and, therefore, were excluded and a final number of 255 forms were retained. Participation in this study was voluntary and anonymous for all participants.

The final sample of the study comprises $60 \%$ of males and $40 \%$ of females. The majority are at the bachelor level $(65 \%)$. The sample also includes $45 \%$ of journalists working in the print media, $25 \%$ in the audio-visual, $20 \%$ in the Bahrain News Agency, and $10 \%$ in the online press. Seventy percent of the sampled journalists work full-time and 30\% part-time. In addition, $60 \%$ of the sample belongs to the youth group (25-35 years old). Most of them have used social media networks for over five years (62\%).

The survey includes 20 questions, divided into quantitative questions and qualitative questions. The combination of the two types of questions gives greater enrichment to the level of results.

The aim of the survey is to understand and examine the adoption of the use of social media factors and their potential impact on journalistic practice as a catalyst in promoting news production and as the fastest way to get news and dissemination, and the opportunity for more communication and interaction with the public. The study also measures the degree of journalist's confidence in social media as a source of news, their impact on the journalist's career and the future of the economic model of the news organization.

As for processing the questionnaire and analyzing the results, Survey Monkey was used in the preparation and compilation of data on the Internet. This is followed by exporting all the data in the form of an Excel file that includes the final numbers and percentages for the answers of quantitative type, and then the results were analyzed more deeply through SPSS, a specialized software in the processing and analysis of data in the humanities and social sciences.

\section{Results}

\section{High Adoption and Use of Social Media in Journalism}

The results show that the vast majority of respondents are not new in the use of social media in journalism, as $62 \%$ of them have used it for more than five years. The significance is reflected in the daily use of the social media as (35\%) of the respondent journalists use them more than 10 times a day and (24\%) between five and 10 times a day. These figures are high, underscoring the growing and daily reliance on the use of social media as new tools to assist in all areas and stages of the journalistic production. This finding also agrees with the Global Social Journalism Study (Cision, 2017), which emphasizes the high use of social media by American journalists, in addition to The Digital News Report of the Reuters Institute of Oxford University (Newman et al., 2017), which also confirms the increase in the dissemination of news via social media.

Males appear to be more likely to use social media in journalism (78\% use it more than 10 times a day) than females (75\% use less than 5 times a day). The average daily use of social media among young respondents is gradually increasing compared with those of the older age group. This is a normal result, consistent with international standards (ITU, 2017) in the use of social media and the Internet among the young and the old.

The results also show that full-time journalists are more likely to use social media ( $83 \%$ use it more than 10 times a day) compared to part-time journalists (56\% use it once a day). This may mean that the use of social 
media is gradually taking root in the core work tools of the news organization (Cision, 2017; Newman et al., 2017).

The results show no correlation between the variables of education level and workplace and access to training to analyze the rate of daily use of social media in the press.

Table 1

Rate of the Use of Social Media in Journalism (Number of Times/Day)

\begin{tabular}{lll}
\hline & Frequency & Percentage $(\%)$ \\
\hline Once a day & 45 & 17 \\
Less than five times a day & 60 & 23 \\
Between five and 10 times a day & 60 & 24 \\
More than 10 times a day & 90 & 36 \\
\hline
\end{tabular}

Note. Source: Survey from field analysis, 2018.

\section{The Impact of the Use of Social Media on Journalism}

Statistics indicate that an absolute majority of respondents agree that the use of social media has already improved journalism (88\%). This result is supported by the conviction in newsrooms and news organizations that social media cannot be dispensed with today as one of the tools used to produce, disseminate, and interact with the public (Acharya et al., 2012; Cision 2017; Newman et al., 2017). The extensive use of social media at the personal level has made it easy to adopt and use this new technology in the professional field.

It seems that those working in the print media are less convinced of the role of social media in improving journalism, unlike those in the electronic media who see it as an aid to improving journalism. The results also show that males are less convinced than females about this issue.

Training journalists on using social media is an important element in motivating journalists, as it is an important tool in journalism. Statistics indicate that respondents who have not received training in the use of social media are the least convinced of their positive role in improving journalism.

Table 2

The Impact of Social Media in Improving Journalism

\begin{tabular}{lcc}
\hline & Frequency & Percentage $(\%)$ \\
\hline Yes & 225 & 88 \\
No & 20 & 8 \\
I do not know & 10 & 4 \\
\hline
\end{tabular}

Note. Source: Survey from field analysis, 2018.

\section{The Most Important Social Media Platforms Used in Research and Access to News and Dissemination}

Twitter comes first (90\%) in terms of its use by journalists in searching for and accessing information, followed by Instagram (67\%), WhatsApp (65\%), and YouTube (34\%). Facebook represents only $27 \%$ of the usage rate.

As for the most important social media used in publishing news by journalists, Twitter also ranks first (82\%), followed by Instagram (75\%) and WhatsApp (75\%). The statistics, however, show the relative poor use of Facebook (27\%) and YouTube (25\%) in the process of publishing news by journalists.

On the other hand, and in a negligible rate, some respondents said they use social networking sites differently from the list proposed in the questionnaire, whether to searching for, accessing, or publishing news, including Google Plus and Snapchat. 
We note that relying primarily on Twitter in the search for and publication of news comes in a different rate from the general statistics at the national or global level in terms of the use of social media. Bahrainis generally use Facebook (Kemp, 2018) primarily. This can be explained by the fact that most journalists and political, public, cultural, and artistic figures in Bahrain use Twitter primarily to communicate with the public.

Table 3

The Most Important Social Media Platforms Used in Research and Access to News and Dissemination

\begin{tabular}{llclc}
\hline & & Publishing news & Searching for and accessing news \\
\cline { 2 - 5 } & $\mathrm{N}$ & $\%$ & $\mathrm{~N}$ & $\%$ \\
\hline Twitter & 210 & 82 & 230 & 90 \\
Instagram & 190 & 75 & 170 & 67 \\
WhatsApp & 190 & 75 & 165 & 65 \\
YouTube & 65 & 25 & 110 & 43 \\
Facebook & 70 & 27 & 70 & 27 \\
\hline
\end{tabular}

Note. Source: Survey from field analysis, 2018.

\section{How Important Social Media Are in Researching, Accessing, and Publishing News}

All journalists expressed their belief in the importance of the means of social media in the work of the press, providing them with speed in searching for and accessing news and their publication (100\%). They also believe that social media provide additional sources of journalism (89\%). On the other hand, journalists believed that social media, while important, they are not accurate in searching for and accessing news and their publication $(48 \%)$. This concern is shared by most journalists around the world when using social media (Brandtzaeg et al., 2017; Acharya et al., 2012).

Table 4

How Important Are Social Media in Researching, Accessing and Disseminating News

\begin{tabular}{|c|c|c|c|c|c|c|c|c|c|c|c|}
\hline & \multicolumn{3}{|c|}{ Strongly agree } & Agree & \multicolumn{3}{|c|}{$\begin{array}{c}\text { Neither agree nor } \\
\text { disagree }\end{array}$} & \multicolumn{2}{|c|}{ Disagree } & $\begin{array}{l}\text { ongly } \\
\text { gree }\end{array}$ & \multirow[t]{2}{*}{-Mean } \\
\hline & $\mathrm{N}$ & $\%$ & $\mathrm{~N}$ & $\%$ & $\mathrm{~N}$ & $\%$ & $\mathrm{~N}$ & $\%$ & $\mathrm{~N}$ & $\%$ & \\
\hline Speed/Time & 160 & 63 & 95 & 37 & 0 & 0 & 0 & 0 & 0 & 0 & 1.37 \\
\hline $\begin{array}{l}\text { Additional } \\
\text { sources }\end{array}$ & 110 & 43 & 140 & 55 & 0 & 0 & 5 & 2 & 0 & 0 & 1.61 \\
\hline Precision & 35 & 14 & 65 & 25 & 35 & 14 & 105 & 41 & 15 & 6 & 3.00 \\
\hline
\end{tabular}

Note. Source: Survey from field analysis, 2018.

\section{Areas of Use of Social Media in Journalism}

Respondents use social media in terms of importance in three main areas: (1) searching for information (84\%); (2) publishing breaking news (73\%); and (3) gaining new ideas for news stories (71\%). The statistics show that journalists use social media in other areas, mentioned in order of importance as follows: personal use (65\%). This issue remains complex because the personal use of social media by journalists, particularly at the news level, does not necessarily reflect the views of the news organization, and may create a confusion between what the journalist wants to publish personally and what the institution wants to publish professionally. The completed press releases were published (61\%); instant coverage of events $(51 \%)$, interaction with readers and followers $(55 \%)$, and access to addresses and contact numbers for press sources (49\%). 
In a limited number, journalists use social media to interact with other journalists (35\%) and search for presence through social networks (35\%). Journalists use social media for interviews only in a limited proportion (29\%), while a small percentage of journalists reported that they did not use social media (6\%). There is no correlation between non-use and age, gender or educational variables.

These figures reflect the full or relative adoption of social media as new tools to help journalists accomplish their various journalistic tasks, whether in searching, information gathering, news dissemination, and interaction with readers and followers of in general. Even the few who still resist the use of social media in journalism are forced eventually to adopt this issue (Cision, 2017), because it is not a personal choice, but a strategic choice that the journalism profession and the news organization rely on it more broadly. Thus, based on the theory of acceptance of technology, the adoption of the use of social media by Bahraini journalists has become a key role in changing the work environment and increasing performance, considering the elements of ease of use, speed in the search, publication, distribution, and interaction with the public.

Table 5

Areas of Use of Social Media in Journalism by Relevance

\begin{tabular}{lll}
\hline & Frequency & Percentage $(\%)$ \\
\hline Search for information & 215 & 84 \\
Breaking News publication & 185 & 73 \\
Getting new Ideas for press stories & 180 & 71 \\
Personal use & 165 & 65 \\
Publication of completed press releases & 155 & 61 \\
Interaction with readers and followers & 140 & 55 \\
Immediate coverage of events & 130 & 51 \\
Access to addresses and contact numbers for press sources & 125 & 49 \\
Interaction with other journalists & 90 & 35 \\
Search for presence on social networks & 90 & 35 \\
I do not use social media in journalism & 15 & 6
\end{tabular}

Note. Source: Survey from field analysis, 2018.

\section{High Confidence in News and Information From Official Social Media}

Statistics indicate that respondents generally give high confidence to news and information from official social media. The Bahrain News Agency enjoys a high confidence (Mean $=1.45)$, followed by Bahrain Radio $($ Mean $=1.58)$ and Bahrain TV $($ Mean = 1.63). The social media of the ministries, government agencies, and local newspapers and magazines are also highly trusted by the respondents.

Confidence is gradually reduced about news and information from social media when it comes to accounts of companies, private institutions and personal accounts of journalists, accounts of organizations, non-governmental organizations (NGOs), and political societies.

Respondents show a clear reservation (Mean $=3.27)$ towards news and information from individuals' social media accounts. It shows a great awareness among journalists that information and informal news should be investigated and adopted only after considerable scrutiny in accordance with the ethics of the journalistic profession, and also because of the personal viewpoints that may not be neutral.

With regard to RQ 1, the results of the study confirmed the first and second hypotheses. The younger journalists and journalists trained in the use of social media are more responsive to the use of these tools as a catalyst to promote the process of journalistic production. 
Table 6

The Degree of Trust Towards News and Information From Social Media by Importance

\begin{tabular}{|c|c|c|c|c|c|c|c|c|c|c|c|}
\hline & \multicolumn{2}{|c|}{$\begin{array}{c}\text { Strongly } \\
\text { agree }\end{array}$} & \multicolumn{2}{|c|}{ Agree } & \multicolumn{2}{|c|}{$\begin{array}{c}\text { Neither agree } \\
\text { nor disagree }\end{array}$} & \multicolumn{2}{|c|}{ Disagree } & \multicolumn{2}{|c|}{$\begin{array}{l}\begin{array}{l}\text { Strongly } \\
\text { disagree }\end{array} \\
\end{array}$} & \multirow[t]{2}{*}{ Mean } \\
\hline & $\mathrm{N}$ & $\%$ & $\mathrm{~N}$ & $\%$ & $\mathrm{~N}$ & $\%$ & $\mathrm{~N}$ & $\%$ & $\mathrm{~N}$ & $\%$ & \\
\hline Bahrain News Agency & 165 & 65 & 65 & 25 & 25 & 10 & 0 & 0 & 0 & 0 & 1.45 \\
\hline Bahrain Radio & 150 & 60 & 60 & 24 & 35 & 14 & 5 & 2 & 0 & 0 & 1.58 \\
\hline Bahrain TV & 140 & 55 & 65 & 29 & 35 & 14 & 5 & 2 & 0 & 0 & 1.63 \\
\hline Ministries and government agencies & 100 & 39 & 130 & 51 & 20 & 8 & 5 & 2 & 0 & 0 & 1.73 \\
\hline Local newspapers and magazines & 80 & 32 & 135 & 54 & 10 & 4 & 20 & 8 & 5 & 2 & 1.94 \\
\hline Private companies and institutions & 55 & 22 & 145 & 56 & 55 & 22 & 0 & 0 & 0 & 0 & 2.00 \\
\hline Foreign media & 75 & 29 & 125 & 47 & 45 & 18 & 10 & 4 & 5 & 2 & 2.02 \\
\hline NGOs & 30 & 12 & 130 & 52 & 75 & 30 & 15 & 6 & 0 & 0 & 2.30 \\
\hline Personal accounts of journalists & 25 & 10 & 135 & 53 & 80 & 31 & 15 & 6 & 0 & 0 & 2.33 \\
\hline Political associations & 25 & 10 & 90 & 35 & 95 & 37 & 40 & 16 & 5 & 2 & 2.65 \\
\hline Accounts of deputies and public figures & 35 & 14 & 75 & 29 & 95 & 37 & 45 & 18 & 5 & 2 & 2.65 \\
\hline Individual Accounts & 20 & 8 & 35 & 14 & 70 & 27 & 115 & 45 & 15 & 6 & 3.27 \\
\hline
\end{tabular}

Note. Source: Survey from field analysis, 2018.

\section{The Impact of the Use of Social Media in Developing the Profession of the Journalist}

Most journalists believe that the use of social media has already contributed to the development of journalism (88\%). "Journalists should take advantage of the social media to offer opportunities for practicing and developing the profession of journalism in general", one of the respondents said. In contrast, only a few expressed their rejection of this view (6\%), while the remaining $6 \%$ did not clearly define their position on the positive use of social media or not.

The statistics indicate that journalists who do not see the use of social media as having a positive impact on the development of the journalist's profession are mainly elderly and have little use of these networks in journalism. They also work in the mainstream media (newspapers, radio, and television).

Table 7

The Impact of the Use of Social Media on the Development of the Profession of the Journalist

\begin{tabular}{llc}
\hline & Frequency & Percentage $(\%)$ \\
\hline Yes & 225 & 88 \\
No & 15 & 6 \\
I do not know & 15 & 6 \\
\hline
\end{tabular}

Note. Source: Survey from field analysis, 2018.

\section{The Impact of the Use of Social Media in Enhancing the Relationship With the Public}

Most journalists agree that the use of social media in journalism contributes to the relationship with the public (Uwom et al., 2014). They also see that the combination of traditional journalism and the potential of social media can improve the relationship between journalists and the public. On the other hand, a small percentage of journalists believe that the public is not looking for interaction through social media, but rather search for news.

\section{The Impact of the Use of Social Media on the Future of the Economic Model of the News Organization}

In response to the question of the impact of the use of social media in journalism on the future of the economic model of the news organization, the majority of journalists surveyed believe that the current model, 
which depends on advertising as a basic income for the institution will remain the dominant model (53\%). Others believe that limited subscription to news services will be the future economic model of the news organization (33\%). A number of other journalists expressed their conviction that the future economic model will be affected by the adoption of the monthly or annual subscription of news (24\%). Finally, a small percentage of respondents believe that the combination of free and paid news may be the future economic model of news organizations (22\%).

Table 8

The Impact of the Use of Social Media in Strengthening the Relationship With the Public

\begin{tabular}{|c|c|c|c|c|c|c|c|c|c|c|c|}
\hline & \multicolumn{2}{|c|}{$\begin{array}{l}\text { Strongly } \\
\text { agree }\end{array}$} & \multicolumn{2}{|c|}{ Agree } & \multicolumn{2}{|c|}{$\begin{array}{l}\text { Neither agree } \\
\text { nor disagree }\end{array}$} & \multicolumn{2}{|c|}{ Disagree } & \multicolumn{2}{|c|}{$\begin{array}{l}\text { Strongly } \\
\text { disagree }\end{array}$} & \multirow{2}{*}{ Mean } \\
\hline & $\mathrm{N}$ & $\%$ & $\mathrm{~N}$ & $\%$ & $\mathrm{~N}$ & $\%$ & $\mathrm{~N}$ & $\%$ & $\mathrm{~N}$ & $\%$ & \\
\hline $\begin{array}{l}\text { Use enhances the relationship } \\
\text { with the audience }\end{array}$ & 110 & 44 & 130 & 52 & 10 & 4 & 0 & 0 & 0 & 0 & 1.90 \\
\hline $\begin{array}{l}\text { Integrating the possibilities of } \\
\text { traditional journalism and social } \\
\text { media improves the relationship } \\
\text { with the public }\end{array}$ & 115 & 45 & 120 & 47 & 20 & 8 & 0 & 0 & 0 & 0 & 1.60 \\
\hline $\begin{array}{l}\text { The audience are in need of } \\
\text { news and not interaction }\end{array}$ & 75 & 29 & 20 & 31 & 25 & 10 & 75 & 29 & 0 & 0 & 2.39 \\
\hline
\end{tabular}

Note. Source: Survey from field analysis, 2018.

On the other hand, most of the respondents were fully aware of the impact of free news on social networks and news applications (e.g., Nabth or Sahafa), which would have a major impact on the future of the journalistic business model. This opinion reached the point of pessimism, as one of the respondents stated that "with the means of social media and the worsening role in publishing there will not be any journalist".

To date, there is not enough scientific research to explain the economic model adopted by the news organizations in the Kingdom of Bahrain or to analyze the reliance on new revenue elements that can be used by prepaying to archive or directing advertisements through free subscription to some digital services and even paid subscriptions to some Digital Services (Dagiral \& Parasie, 2010).

Table 9

The Impact of the Use of Social Media on the Future of the Economic Model of the News Organization

\begin{tabular}{lll}
\hline & Frequency & Percentage $(\%)$ \\
\hline Same current model (reliance on ads) & 135 & 53 \\
Limited subscription to Internet users & 85 & 33 \\
Monthly or annual subscription & 60 & 24 \\
payment per piece (e.g. purchase of an article) & 55 & 22 \\
\hline
\end{tabular}

Note. Source: Survey from field analysis, 2018.

With regard to RQ 2, the findings of the study revealed the denial of the first hypothesis. Most interviewees expressed their full awareness of the change in social media in journalism. It also denied the results of the third hypothesis since there is no correlation between the degree of awareness of the change in journalism using means of social media, and type of work (full/partial). In contrast, the results of the study confirmed the second hypothesis, and showed that older journalists are more aware of these changes in the profession of journalism. 


\section{Discussion and Conclusion}

The results of the study of the factors influencing the adoption and use of social media and its impact on mainstream media in the Kingdom of Bahrain, which fall within the framework of the theory of acceptance of technology (Davis, 1989), showed a clear adoption and a high and increasing use of social media in journalism at all stages, especially in the area of searching for information, publishing breaking news, accessing new ideas for news stories, and promoting more interaction with the public.

In their work, Bahraini journalists use three basic social media platforms: Twitter, Instagram, and WhatsApp. They believe they are useful tools to help them search, get instant news, and provide additional resources. Nevertheless, they expressed concern about the lack of precision that characterizes these means and fear of the negative effects on the professional journalist.

Journalists tend to give greater confidence to news and information from social media accounts of official media and official government agencies, while they lack confidence in individuals' accounts, which they regard as sources of poor reliability.

Journalists also believe that the adoption and use of social media has a positive impact on the development of journalism and the future of the news organization in general. They also believe that the combination of the potential of traditional journalism and the potential of social media can improve the relationship between journalists and the public.

The results of the study clearly show the acceptance of Bahraini journalists of this new technology of social media, which reinforces the idea that adopting and using this technology in journalism contributes to the creation of a better working environment and improves performance, despite the new problems related mainly to the difficulty of complete commitment to the professional controls and the debate about the precision and credibility of the information made available by social media in general.

\section{References}

Acharya, U., Pathak, B., Karki, B., Bhandari, R., \& Dahal, U. (2012). Journalist and social media: A national survey of Nepali journalists on their use of Internet and social media. Nepali Journal of Contemporary Studies, 12(2), 21-38.

Alsridi, H. (2011). Bahraini online newspapers: A study on the assessment of user interface and access to information. Thaqafat, $24,116-129$.

Alsridi, H. (2018). The use of the Internet and the practice of journalism in Bahrain. Journalism and Mass Communication, 8(4), $175-186$.

Amjad, O. (2018). Social media research on changing the roles of journalists. Journal of New Media and Mass Communication, $5(1), 1-13$.

Anderson, C. W. (2011), Between creative and quantified audiences: Web metrics and changing patterns of newswork in local US newsrooms. Journalism, 12(5) 550-566.

Apuke, O. D. (2016). The impact of social media on conventional journalism practice in Nigeria: A study of journalists' in Jalingo Metropolis. Canadian Social Science, 12(12), 59-65.

Bahrain Journalists Association. (2018). Bahrain Journalists Association. Retrieved from http://goo.gl/6nV7HC

Bastos, H., Lima, H., \& Moutinho, N., (2010). The influence of the Internet on Portuguese press. Proceedings of the International Association for Media and Communication Research (IAMCR) Conference, September 18-22, Braga, Portugal,

Bastos, H., Lima, H., Moutinho, N., \& Reis, I., (2012). Radio journalists and the Internet: A study on perceptions. Proceedings of the Radio Evolution Conference, September 14-16, Braga, Portugal.

Ben Moussa, M., \& Douai, A., (2014). The digital transformation of Arab news: Is there a future for online news after the "Arab Spring"? Journal of Applied Journalism \& Media Studies, 3(2), 133-154.

Bossio, D. (2017). Journalism and social media: Practitioners, organisations and institutions. Berlin: Springer. 
Brandtzaeg, P. B., Følstad A., \& Domínguez, A. M. C (2017). How journalists and social media users perceive online fact-checking and verification services. Journalism Practice, 12(9), 1109-1129.

Bullard, S. B. (2013). Social media and journalism: What works best and why it matters. Proceedings from the National Convention of the Association for Education in Journalism and Mass Communication, Washington, D.C., Aug. 10, 2013.

Chang-de, L. (2015). Facebook journalism: The influences of social media on journalistic work in Taiwan. Proceedings of the First International Conference on Innovative Communication and Sustainable Development in ASEAN. 16th to 17th July, Bangkok, Thailand.

Chuttur, M. (2009). Overview of the technology acceptance model: Origins, developments and future directions. Sprouts: Workings Papers on Information Systems, 9(37), 1-22.

Cision. (2017). Global social journalism study. Retrieved from http://goo.gl/wrjQwj

Dagiral, E., \& Parasie, S. (2010). Presse en ligne: Où en est la recherche? (Online press: has research progressed?). Réseaux, 28(160-161), 13-42.

Davis, F. D. (1989). Perceived usefulness, perceived ease of use, and user acceptance of information technology. MIS Quarterly, 13(3), 319-340.

Dennis, E. E., Martin, J. D., \& Wood, R. (2017). Media use in the Middle East, 2017: A six-nation survey. Retrieved from https://goo.gl/KiKvj5

Didiugwu, I. F., Ezugwu, Z. I., \& Ekwe, O. C (2015). A discourse on the use of social media by journalists in Nigeria. Developing Coubtry Studies, 5(18), 133-140.

Fortunati, L., Sarrica, M., O’Sullivan, J., Balcytiene, A., Harro-Loit, H., Macgregor, P., ... De Luca, F. (2009). The influence of the Internet on European journalism. Journal of Computer-Mediated Communication, 14, 928-963.

ITU. (2017). Measuring the Information Society Report (Volume 1 \& 2). Retrieved from http://goo.gl/G3iHvr

Kemp, S. (2018). Digital in 2018 in essential insights into Internet, social media, mobile and ecommerce use across the region. Retrieved from http://goo.gl/FD3MxK

Lee, J. (2015). The double-edged sword: The effects of journalists' social media activities of audience perceptions of journalists and their news products. Journal of Computer-Mediated Communication, 20(3), 319-329.

Mansour, E. (2016). The adoption and use of social media as a source of information by Egyptian government journalists. Journal of Librarianship and Information Science, 50(1), 48-67.

Matsa, K. E., \& Shearer, E. (2018). News use across social media platforms 2018. Retrieved from http://goo.gl/N25v1p

Neelima, B. N. (2015). Impact of social media on mainstream journalism. Retrieved from http://repository.kln.ac.lk/handle/123456789/11129

Newman, N. (2009). The rise of social media and its impact on mainstream journalism: A study of how newspapers and broadcasters in the UK and US are responding to wave of participatory social media, and a historic shift in control towards individual consumers. Retrieved from https://reutersinstitute.politics.ox.ac.uk/sites/default/files/2017-11/The\%20rise $\% 20$ of $\% 20$ social\%20media $\% 20$ and $\% 20$ its $\% 2$ 0impact\%20on\%20mainstream\%20journalism.pdf

Newman, N., Fletcher, R., Kalogeropoulos, A., Levy D., \& Nielsen, R. (2017). Reuters Institute Digital News Report 2017. Retrieved from https://reutersinstitute.politics.ox.ac.uk/sites/default/files/Digital\%20News\%20Report\%202017\%20web_0.pdf

Pavlic, J. (2010). The impact of technology on journalism. Journalism Studies, 1(2), 229-237.

Salem, F. (2017). The Arab Social Media Report 2017: Social media and the Internet of Things: Towards data-driven policymaking in the Arab World. Retrieved from http://goo.gl/FdBCyM

Uwom, O. O., Ajaegbu, C., Oloyede, D. B., \& Sowemimo-Coker, S. (2014). Prospects of Internet technology in news production: A study of Voice of Nigeria and Nigeria television authority. Global Journal of Arts Humanities and Social Sciences, 2(1), 55-66.

Van Der Haak, B., Parks, M., \& Castells, M. (2012). The future of journalism: Networked journalism. International journal of Communication, 6, 2923-2938. 